\begin{tabular}{|l|l|l||}
\hline \multicolumn{2}{|c|}{ PublisherInfo } \\
\hline \hline PublisherName & $:$ & BioMed Central \\
\hline \hline PublisherLocation & $:$ & London \\
\hline \hline PublisherImprintName & $:$ & BioMed Central \\
\hline \hline
\end{tabular}

\title{
Evolving without sex
}

\begin{tabular}{|l|l|l||}
\hline \multicolumn{2}{|c|}{ ArticleInfo } \\
\hline \hline ArticleID & $:$ & 4280 \\
\hline \hline ArticleDOI & $:$ & $10.1186 /$ gb-spotlight-20011218-01 \\
\hline \hline ArticleCitationID & $:$ & spotlight-20011218-01 \\
\hline \hline ArticleSequenceNumber & $:$ & 351 \\
\hline \hline ArticleCategory & $:$ & Research news \\
\hline ArticleFirstPage & $:$ & 1 \\
\hline \hline ArticleLastPage & $:$ & 2 \\
\hline \hline & $:$ & RegistrationDate : 2001-12-18 \\
ArticleHistory & $:$ & OnlineDate \\
\hline \hline ArticleCopyright & $:$ & BioMed Central Ltd2001 $12-18$ \\
\hline \hline ArticleGrants & $:$ & \\
\hline \hline ArticleContext & $:$ & 130592211 \\
\hline \hline
\end{tabular}




\section{Jonathan B Weitzman}

Email: jonathanweitzman@hotmail.com

Arbuscular mycorhizal fungi, which have lived for 400 million years without sex, present a challenge to evolutionary theories about the role of sex. In the December 13 Nature Gerrit Kuhn and researchers at the University of Lausanne, Switzerland, discuss genetic variation within Arbuscular mycorhizal fungus individuals, which contain hundreds of inherited nuclei (Nature 2001, 414:745-748). They carried out specific DNA-DNA FISH (fluorescent in situ hybridization) analysis to show that fungal spores contain a population of genetically different nuclei, and used phylogenetic analysis to conclude that the genetic variations are due to accumulation of mutations in a clonal genome and not to recombination. These results highlight the difficulties of applying standard evolutionary and population genetics theories to multi-genomic organisms.

\section{References}

1. Evolutionary genetics. Sinless originals.

2. Nature, [http://www.nature.com]

3. University of Lausanne, [http://www.unil.ch/] 